\title{
Myanmar's Foreign Policy Towards Its Near Neighbours
}

\author{
N. GANESAN ${ }^{* *}$
}

This article examines the evolution of Burma/Myanmar's foreign policy in terms of its ideological orientations and evolution. The collapse of the Burma Socialist Programme Party (BSPP) government in 1988 that had previously pursued a policy of neutrality obtained through self-imposed isolationism has been replaced by a much more realist foreign policy that views international relations and power in competitive terms. Myanmar also maintains a set of competitive relations with its near neighbours to stabilize the immediate external environment and stave off the impact of international sanctions. These bilateral relations are also calibrated to provide a balance-of-power between the three sets of relations in order to avoid being overwhelmed by any of them. All three near neighbours have many important and sensitive issues that are brought to bear on the relationships as well.

Keywords: Myanmar's foreign policy, Myanmar-China relations, Myanmar-India relations, Myanmar-Thailand relations, Near neighbours.

Revised version of a paper delivered at the conference Political Developments and New Challenges for International Relations in Southeast Asia, July 19-21,2009, Yunnan University, Kunming. China. The author would like to thank Dr. Kyaw Yin Hlaing and the three anonymous referees for their

.. comments on the article.
Professor of Southeast Asian Politics, Hiroshima Peace Institute, Hiroshima City University;

E-mail: ganesan@ peace.hiroshima-cu.ac.jp 


\section{INTRODUCTION}

$\mathrm{B}$

urma/Myanmar's foreign relations have been subjected to significant changes from the late 1980s. ${ }^{\text {Th }}$ This article examines the domestic contours and considerations in Myanmar's foreign policy output and the nature of its relations with its near abroad-China, India and Thailand. The term "near abroad" (blizhneye zarubezbe) was in vogue from the 1950 s to the 1980 s and was often used to describe the Soviet Union's relations with its satellite states (Cameron and Domanski 2005). This early strategy which began from the time of Tsarist Russia was aimed at providing security for the country through the control of immediately adjacent buffer states. In this instance however, the term does not carry such unequal connotative value but simply asserts the importance of Myanmar's bilateral relationships with its immediate neighbours.

Myanmar's foreign policy is derived from a core of elite interests that has been identified as the "political-security complex" that sustains the military junta in power and deflects domestic political challenges (Haacke 2006, 17-19). This internal consideration, like in many developing Asian countries, conflates regime security with state security (Waltz 1959; Alagappa 1998). In theoretical terms, it also falls well within the tradition of what James Rosenau (1969) called linkage politics -domestic interests that impinge on a state's foreign policy output. Generally however, Myanmar's foreign policy output is delivered within the realist tradition that attempts to obtain and enhance national power in competitive terms (Morgenthau 1948). This comperitive world view is then supplemented through a classic balance-of-power approach with its near neighbours that seeks to stabilize the immediate external environment and cushion the country from the vagaries of an international sanctions regime led by the United States (US) and the European Union (EU).

Organizationally, this essay is divided into five major sections. The first section examines normative values that have informed Myanmar's foreign policy as well as significant historical junctures that have led to major shifts in these policy positions. The next three sections examine Myanmar's bilateral relations with China, India and Thailand respectively. Finally, the last section examines the significance of Myanmar's bilateral relations within the larger scheme of things.

\section{SIGNIFICANT HISTORICAL CONJUCTURES AND POLICY PRIORITIES}

Burma, together with the Indian sub-continent and Malaya, was colonized by Britain in the Eighteenth Century. The process of colonization had two distinguishing features. The first of these was the high level of violence involved in the subjugation of the country-the British fought a total of three wars that 
came to be referred to as the Anglo-Burmese Wars and ruled the country in a piecemeal fashion from India (Callahan 2004). The second unique feature was the fact that the British, up to the time of independence, had relatively little control over the highland areas that were typically populated by ethnic minorities. Hence, British control over Burma tended to be restricted to the lowland regions in what came to be called Ministerial Burma. Nonetheless, the British maintained a certain truce with the highlanders, and during the Second World War, recruited a large number of Kachin, Chin and Karen to fight Japanese occupation troops. At the time when Burma was granted political independence in January 1948, this broad-based division of the country continued.

Burma's foreign relations with the external world were a function of domestic political developments as well as a number of important general perceptions. In terms of important political developments, major historical conjunctures occurred in 1962 when the military wrested power from the civilian government and in 1988 when the Burma Socialist Programme Party (BSPP) government collapsed. Depending on how well the developments are nuanced, 1990 may be added as an important year when the outcome of nationwide elections called by the military government was annulled. The successor military government was renamed the State Law and Order Restoration Council (SLORC) in 1988 and in 1997. it was renamed the State Peace and Development Council (SPDC). Whereas leadership transition in 1988 was marked by a high level of political violence against the democracy movement, subsequent developments, at least in the lowlands, have tended to be less violent. It may be noted however that since 1962, notwithstanding important developments, there has been leadership but not regime transition. ${ }^{2}$

The importance of noting significant conjunctures lies in the fact that these cpisodes affected the country's foreign relations. Since 1988 onwards, relations with Western countries, in particular the US and EU have deteriorated significantly. Myanmar's relations with major Asian powers have tended to be rather mixed -relations with India has been subjected to some turbulence, those with Japan were subjected to external pressures and political considerations, but relations with China have certainly improved. Relations with Thailand have been quite complicated and nuanced, just like those with many of the other ASEAN countries (Ganesan 2006).

As a medium-sized and relatively underdeveloped Asian country, Burma's foreign policy has generally tended to be reactive rather than proactive. The relative inability of the country to determine or influence international relations was realized by the indigenous elite rather early on. Burma, not unlike Indonesia, upon independence, professed an independent and non-aligned foreign policy. Nonetheless, both conditions are dependent on actions as well as circumstances. For all its assertions, independence and non-alignment evaded the country. It began in the first instance owing to the presence of a large detachment of 
Chinese nationalist Kuomintang (KMT) regular troops and deserters in the Shan states. This troop presence was complicated by communist China's interest in consolidating its own political situation and sovereignty by defeating the KMT threat. To make matters worse, the U.S., through the Central Intelligence Agency (CIA), funded and equipped this KMT detachment to attack and create instability in communist China. Hence, as soon as Burma obtained its political independence, it was dragged into the Cold War, notwithstanding its foreign policy pronouncements. It may therefore be argued that from 1948 to 1961, Burma's most important external relations were not of its own choosing or making (Ganesan 2005).

These early developments not only had a sobering effect on the government, but more importantly, reinforced a preexisting elite perception. From the time of British colonization, Burmese elite began to distrust foreigners and foreign interests. Although such elite perceptions were common during the later colonial period in most Asian and African countries, post-independence elite typically reconciled themselves to the structural dictates of the international system and tended to retain some linkages with their colonial masters. Burma ended such linkages fairly early on, at least in part owing to negative sentiments on both sides regarding resistance to Japanese imperialism and the role of the highland minorities in the post-independence period (Callahan 2004). The negative perception of foreign countries and the nature of their interests also spilled over into Burma's appraisal of the larger Asian powers. Domestic elite were always conscious of the fact that the country is sandwiched between two large Asian powers -China and India-and retain historical memories of Japanese power and Thai enmity.

In view of the circumstances surrounding Burma's post-independence experience with foreign countries, a number of gencralizations may be made regarding the country's disposition to its external environment. Firstly, historically, the country's elite has always been queasy and suspicious about foreign interests and, in particular, Western interests. Consequently foreign policy output has typically been delivered within a realist framework that emphasizes the acquisition and enhancement of power in competitive terms. A second generalization is elite realization that the country has little or no leverage to alter the tone and temper of international relations. Although Burma declared its foreign policy principles repeatedly from 1948 to 1961 , many of its dealing with foreign countries were literally beyond its control. Therefore the frustration of early ideational norms was quickly replaced by a more sober realist outlook. As a result, from 1962, when the military staged a coup against the civilian government, it became introverted and attended to internal matters. By this time, threats deriving from the KMT had dissipated. Consequently, in place of a simply declared policy of non-alignment, beginning from 1962, it adopted a policy of neutrality that was obtained through self-imposed isolationism. This second and more active 
policy of neutrality characterized the foreign policy output during the entire tenure of the BSPP government (Ganesan 2005).

Since the 1990s the Myanmar government demonstrated much greater willingness to engage the international community and actually joined the Non-Aligned Movement in 1992 (Taylor 2009). Nonetheless, Western-led sanctions forced it to demonstrate greater latitude and initiative in foreign policy formulation towards its near Asian neighbours-countries that it has historically distrusted. The Association of Southeast Asian Nations (ASEAN) decision to offer Myanmar membership in the organization in 1997 significantly empowered the country in terms of regional representation and accommodation. ASEAN members came to realize over time that Myanmar could not be swayed notwithstanding its membership in the grouping. In fact, ASEAN member countries like Indonesia, Malaysia, the Philippines, Singapore and Thailand became very critical of Myanmar. Yet, ASEAN's deeply cherished non-interference principle provided Myanmar shelter from criticisms within ASEAN. And within the realist tradition and elite interests that defined Myanmar's foreign policy, the sovereignty principle provided some shelter as well. Countries like China and India have often held positions in international fora that are substantially different from that of the West writ large in order to articulate their own interests and concerns. And Myanmar appears to have found useful allies in such countries. Also, larger non-Western countries are equally anxious not to perpetuate a culture of external involvement in the resolution of domestic political problems. Myanmar appears to provide just such an example of Western attempts at intervention.

Conversely, since 1988, Burma/Myanmar has attracted much international and especially Western attention. Most of such attention pertains to domestic political developments, in particular the violence associated with the 1988 protests for democracy, the annulment of the 1990 election results and the detention of opposition politicians. Whereas self-imposed isolationism allowed the country to cocoon itself during the BSPP period, by 1988, the world had become significantly more interdependent, communications and technology had improved vastly, and socialism had become widely discredited. The Western euphoria that greeted the collapse of communism was accompanied by an equally euphoric tendency to promote the virtues of liberal democracy globally. As a result, the military elite that headed the country was simply overwhelmed by the amount of international attention that the country has been subjected to since then. Both the $\mathrm{US}$ and the EU have led the international community in imposing wide ranging sanctions on the country. In 1990, the U.S. Customs and Trade Act called for economic sanctions against Myanmar and since then, the sanctions regime has been significantly enhanced (Bray 1995). There is also a very critical and vocal Myanmar migrant community that brings pressure to bear on the U.S. government in its dealings with Myanmar. A number of vocal US senators like Mitch McConnell have also maintained a hard line in U.S. dealings with Myanmar. 
Consequently, in 1997, the sanctions bill was expanded to cover new investments as well. As a result, developmental aid from engaged European countries like Germany and the United Kingdom is often funneled through local and foreign NGOs. In fact, many European NGOs maintain a strong presence in Myanmar and are involved in developmental work at the ground level.

The tremendous negative publicity given to the tatmadaw's (army) treatment of the political opposition and the forced use of unpaid labour and prisoners as porters for military offensives against ethnic insurgents eventually led to the Geneva-based International Labour Organisation (ILO) to sanction Myanmar in 2001. The detention of Aung San Suu Kyi after a violent confrontation between the NLD and the Union Solidarity Development Association (USDA) in May 2003 led to a significant expansion of the U.S. sanctions regime, including the banning of all imports, freezing of all financial assets and property holdings of junta members, and halting all foreign remittances (Kyaw 2004). The Bush administration was fundamentally at odds with the Myanmar government and although the Obama administration is beginning to signal greater latitude in its dealings with Yangon in 2009, the arrest, trial and extended detention of Aung San Suu Kyi for violating the terms of her house arrest in May may well frustrate such attempts. There is a general suspicion that negative developments related to the terms of her detention are essentially meant to deprive Suu Kyi of the chance to contest in the 2010 national election. Notwithstanding the fractured nature of the domestic political opposition, Suu Kyi is charismatic, remains immensely popular as an icon and is capable of galvanizing the political opposition and general population. The election was scheduled after Myanmar revised its Constitution and hurried through a referendum endorsing the new Constitution in May 2008 shortly after Cyclone Nargis devastated the country's delta areas in the south.

\section{MYANMAR'S RELATIONS WITH CHINA}

Myanmar's relationship with China was difficult from the time of its independence in 1948 to the end of the BSPP government in 1988. Despite recognizing communist China early on in 1949. Myanmar's problems with China pertained to security in the first instance. The approximately 16,000 KMT soldiers who had settled in Burma organized attacks against communist China that had already involved itself in the Korean War. CIA support for the KMT soldiers further complicated the situation. Chinese support for the Burmese Communist Party (BCP) added on to the government's woes of stabilizing domestic politics. Hence, from very early on, although the civilian government in Burma decided to steer clear from great power rivalry and pursue an independent and non-aligned foreign policy, the ability to exercise such a policy was clearly elusive. Burma's elite thus concluded 
that the greatest threat to the country's security actually obtained from China (Taylor 1986; Bray 1995; Callahan 2004). The KMT threat receded by 1961, although the BCP threat continued until 1988 when the guerilla armies achieved multiple truces with the government and were disbanded and resettled. Accordingly, from 1988, Myanmar's relations with China have become much more cordial. At the present time, the general consensus is that China-Myanmar relations are extremely strong and that China is Myanmar's most important trade partner and benefactor. The relationship is often characterized as "paukphatw" in the local language, or one involving brothers or siblings.

The political violence associated with the 1988 uprisings and the annulment of the 1990 election results led to Myanmar's international diplomatic isolation. The dissipation of the BCP threat, combined with the difficult domestic situation, provided a window of opportunity for Myanmar and China to rework their bilateral relationship. The Tien An Men incident in 1989 and the general decline of socialism globally were presumably other important factors for China. Myanmar's geographical location between India and China, opportunities arising from the long common border between both countries, and Myanmar's long coastline along the Andaman Sea and Indian Ocean appear to be motivating factors for China. Myanmar, on the other hand, is generally appreciative of strong and unconditional diplomatic support, trading opportunities and aid and weapon procurements. Official relations between the two countries are strong and cordial and there are frequent visits by high-ranking officials between both countries Mya Maung 1998; Muni 2001; People's Daily 2003). ${ }^{3}$ China also continues to affirm that domestic political developments in Myanmar should not be subjected to external pressures or interference as these would compromise the country's sovereignty (China Daily 2003). Such an approach is articulated within the framework of a good neighbourliness policy and is well within the military junta's attempt to uphold state sovereignty.

To begin with strategic and political interests in the bilateral relationship, China has approached the relationship within the framework of a broader regional policy that is partly aimed at stabilizing and consolidating its interests and influence in Asia. It is also aimed at cultivating allies on broader policy positions and common ideational values against Western countries, and in particular the United States on issues like democracy, press freedom and human rights. Apart from securing its borders and stabilizing the external environment, many analysts also point to Chinese interest in gaining access to sea ports and facilities along Myanmar's coastline. Such access has allegedly included the development of road linkages as well as naval facilities for surveillance and eavesdropping (Chi 1997; Maung 1998; Seekins 1997; Selth 1997). ${ }^{4}$ In this regard, China has explicitly expressed an interest in naval access to the Indian Ocean, much to the chagrin of Thailand and especially India, which maintains major naval facilities in the Andaman Islands (Malik 1997).5 On the Myanmar side of the equation, maintaining 
cordial relations is important in securing the border areas and having a large power ally in the immediate vicinity to deflect internal and external threats. China, since 1989, has consistently supported Myanmar politically and reaffirmed the legitimacy of the regime. An important feature of the latter, especially for domestic political consolidation, has been the regular supply of weapons from China (Chi 1997; Military Balance 1998-1999; 2000-2001; Selth 2002).6 Additionally, at the international level, it has helped stave off punitive sanctions and defended Myanmar on issues pertaining to political reform and human rights. Privately and more subtly, it has persuaded Myanmar to progress on its roadmap towards democracy in order for the SPDC to acquire greater domestic political legitimacy. It has also been active in offering its good services to facilitate the visit of United Nations envoys to Myanmar, in particular that of Ibrahim Gambari.

Economic cooperation between the two countries has also developed very significantly in the post-1988 period. Cross-border trade, in particular from Yunnan province in China, into Kachin, Chin and Shan states in Myanmar has been significantly enhanced. Bilateral trade thus far appears to have been profitable for both countries and has escalated dramatically since the 1990s. Since 2006, China has been Myanmar's second largest trading partner after Thailand and in 2008 , the total value of bilateral trade was \$2.63 billion, a 26.3 percent growth from the previous year. In line with the terms of the China-ASEAN FTA, China has lowered tariffs and provided "favourable tariff status" to some 220 products from Myanmar (Xiao 2009). On the Chinese side of the border, the three major trading districts in Yunnan province are Yingjiang, Lungchuan and Tengchung while on the Myanmar side the link to Mandalay is via the Shan cities of Lashio and Muse via the Chinese cities of Wanding and Ruili. The legalization of cross-border trade since 1989 has also led to the construction of bridges and roads along the old Burma Road, the Silk Road and the Ledo Road in the 1990s to encourage cross-border trade. Both countries have promised to usher an era of "relatives born together" (swemyo pauk hpaw) (Maung 1994, 186-7). In 1996, joint fisheries agreements were also signed between both countries, allowing 300 Chinese trawlers access to Myanmar waters and a joint-venture cold storage facility (Davis 1999). China has also been involved in the exploration and purchase of oil and gas from Myanmar and is significantly involved in the provision and upgrade of the country's infrastructure. Such projects have typically included port and storage facilities, hydroelectric power plants along the Mekong and Thanlwin rivers, suspension bridges, satellite and television transmission stations and the provision and maintenance of roads. China is also keen on establishing a road and rail network linking Kunming in Yunnan province to the port of Sittwe in Myanmar's Rakhine state.

In the main, the China-Myanmar bilateral relationship is deemed to be in the neighbourly interest of both countries. There is a good measure of convergent political and economic interests. However, there are also a number of areas 
where the relationship is regarded as potentially injurious to Myanmar. Chief among such concerns is the fear that diplomatic and moral support and weapon sales by China has significantly altered the size and capability of the Myanmar military, significantly leveraging it vis-a-vis other social forces and made the process of domestic political reconciliation much more difficult. In other words, the distributive impact of the positive relationship is highly skewed in favour of the military. There are also some fears regarding Myanmar's overly close alignment with China on economic and political matters, both domestically and externally. Domestically, there is some evidence of unease among residents along the border areas regarding the pervasive impact of China in terms of overwhelming the domestic population and culture (Seekins 1997; Maung 1994). Both the trade and political relationship are generally perceived to be asymmetrical, in China's favour, although it should be noted that the high level of fluctuation in the foreign exchange rate of the Myanmar Kyat and the high level of inflation are not necessarily in China's economic interest. Issues related to ethnicity and culture is also sensitive in the border areas where these have in the past been correlated to insurgency and the production of natural and synthetic drugs (Arnott 2001; Nation 2009; Reuters September 4, 2009). 7 These issues have a tremendous bearing on the political-security complex mentioned at the outset and have the potential to threaten elite and regime interests.

China's public security border defense brigade regularly launches cross-border operations with the Myanmar military from Yunnan province, and in the first quarter of 2009 alone interdicted 182 cases of drug trafficking (Xia 2009). Chinese border troops at Xishuangbanna in southern Yunnan confiscated some 140 kilograms of drugs during the first half of the year. China has also taken a hard line in combating illegal gambling by its officials on the Myanmar side of the border. In a famous incident, it dispatched the military to repossess official cars that were seized by a casino in lieu of cash at the border in Mongla, in Special Region 4, that is controlled by the Shan State Army (SSA). Subsequently, pressure was brought to bear on the Myanmar government to close down the casino. Notwithstanding these hiccups, there is some evidence to suggest that the political elite in Myanmar is aware of such sensitivities and complications, and has in the past been deft in dealing with them and avoided being overwhelmed by China (Davis 1999; Steinberg 2001). ${ }^{8}$ Additionally, Myanmar has sought to balance this bilateral relationship with recent and more positive overtures towards India and Russia.

Externally, the situation is complicated by the fact that a strong bilateral relationship between China and Myanmar will tilt the regional balance of power in China's favour. India, Thailand, and ASEAN countries in general, especially those with external threat perceptions pointing in the direction of China like Indonesia and Vietnam, have been uncomfortable with the relationship. Generally, however, the current trajectory of positive bilateral relations is set to continue and many analysts regard the China-Myanmar bilateral relationship as perhaps the most 
significant of China's bilateral relationships in Southeast Asia at the present time.

\section{MYANMAR'S RELATIONS WITH INDIA}

India is the other large Asian power after China that flanks Myanmar. Owing to the common historical experience of British colonization, Myanmar-India relations have been conducted formaliy for some time now. The bilateral relationship, unlike the case with China, began on a cordial footing and subsequently deteriorated after the violence associated with the crackdown on the 1988 democracy movement. Indian policy output then became ideological in nature and there were public pronouncements and diplomatic actions in support of Aung San Suu Kyi and the National League for Democracy (NLD). Since about 1992, however, following the death of Rajiv Gandhi, Indian policy output has been considerably less ideological and much more realist in its orientation. Indian policy towards Myanmar appears to be at least partly motivated as a reaction to strong Myanmar-China relations and with a view to stabilizing the strategic equation (Steinberg 2001).

Like China, India shares a long common border with Myanmar in the northeast. Myanmar also has a long coastline that taces India along the Bay of Bengal and the Andaman Sea." In the immediate post-independence period, India provided Myanmar with 10,000 small arms together with Britain, and assisted the latter in raising funds in the British Commonwealth. Immediately prior to the 1958 national election, India also offered Myanmar a loan of \$46 million (Taylor 1987). Politically and ideologically, apart from common historical experiences. both countries shared the common articulation of an independent and non-aligned outlook in foreign policy. As Myanmar became inward-looking following the 1962 military coup, relations between the two countrics generally remained fair. Since 1988, however, there have been dramatic changes in the bilateral relationship, beginning with a hostile attitude between the two before the situation became positive again in the 1990s. The Myanmar-India bilateral relationship appears to be more affected by political and strategic considerations rather than economic ones. As in the case with China, there are some ethno-cultural considerations. However, unlike the case with China, there are some rather serious considerations pertaining to insurgent activities along the common border-again issues that threaten the military-security complex and elite and regime interests as well.

The deterioration of the bilateral relationship from 1988 was in large measure owing to India freezing its relations with Myanmar. Additionally, the Indian government opposed the SLORC government and expressed open support for the pro-democracy movement. It sympathized with Myanmarese students and activists and had the equivalent of an open door policy towards such activists along the common border. At the state level, the mass media condemned the 
political situation in Myanmar. It was also reported that India provided some technical and financial assistance to the Kachin Independence Organisation (KIO) and the Karen National Union (KNU) through its consulate in Chiangmai (Egreteau 2003; Malik 1997). ${ }^{10}$ The aim of such involvement was apparently to assist Myanmar return to democracy.

In terms of political and strategic concerns, the Indian decision to engage Myanmar is at least partly derived from threat perceptions linked to the positive relations between China and Myanmar since 1989. It is generally thought that the turning point in the relationship took place as a result of India's "Look East" policy, as well as the visit of the Indian Foreign Secretary J. N. Dixit to Yangon in March 1993. Since then, India has considerably toned down its support for the democracy movement and regards internal developments in Myanmar as purely domestic issues-a position much closer to that of China as well as many ASEAN countries. The situation improved considerably with this new seemingly realist orientation.

A major consideration in India's policy towards Myanmar is ethnic insurgency in the border areas. Shortly after the signing of a Common Border Trade Agreement between the two countries in January 1994, the armies of both countries launched a joint operation against ethnic insurgents in 1995 called "Golden Bird". 11 The operation however suffered from a lack of trust on both sides as a result of seeming Indian support for the democracy movement with the Nehru Prize being awarded to Aung San Suu Kyi the same year. From 1998, the Indian governments led by Prime Minister Vajpayee and Manmohan Singh have concentrated more on nuclear issues and deteriorated relations with Pakistan, although the bilateral relationship with Myanmar was significantly strengthened through official visits on both sides to reaffirm cordial ties (Thin and Soe 2001; Xinhua November 24, 2008). 12 Apart from such visits, India has also undertaken a number of iniciatives in order to express goodwill and support for the current government in Myanmar. Such activities include less liberal policies towards political and student activists from Myanmar and closer cooperation with its military government (Thin and Soe 2001).13 For India, the strategic equation is also coloured by growing ties between Pakistan and Myanmar and their triangulation with China. India believes that such a situation is directly correlated to the amount of leverage that China is able to exert on Myanmar and against Indian interests (Malik 1994). As a result of the strengthened bilateral relationship between India and Myanmar, the Indian Consulate in Yangon and Mandalay were officially reopened in 2002 and Myanmar reciprocated with a Consulate in Calcutta. Aung San Suu Kyi's detention since May 2003 has invited criticisms from India, although the response has been much more measured and discreet, so as not to negatively affect the bilateral relationship.

In terms of economic relations between the two countries, the level of cooperation and trade is significantly lower than the relationship with China. The Border 
Trade Agreement of 1994 only allows for the trade of some 22 items and the overall trade between the two countries in 2001-2002 reached a value of $\$ 323.4$ million (Egreteau 2003). Trade between the two countries is coordinated by the Confederation of Indian Industries (CII) that expressed a desire to increase total bilateral trade to the tune of $\$ 2$ billion by 2003. However, joint bilateral trade only stood at a total of $\$ 995$ million for fiscal year 2007-08, despite India being Myanmar's fourth most important trading partner (Xinhua November 24, 2008). India's major exports to Myanmar are primarily chemicals, cosmetics, pharmaceuticals, and engineering and building goods. On the other hand, it imports lentils, spices, wood products, sugar, fruits and nuts from Myanmar in turn. However, the trade balance is significantly in Myanmar's favour by a 1 to 8 ratio since India imports much more than it exports. More recently, there has also been a small shipment of weapons (Asian Tribune 2002). ${ }^{14}$

Other than direct economic linkages, India has tried to include Myanmar in regional cooperation fora in South Asia. Such efforts include the BIMST-EC initiative (Bangladesh, India, Myanmar, Sri Lanka and Thailand Economic Cooperation) launched in 1997, the Mekong-Ganga Cooperation project (MGC) launched in July 2000, in seeming response to China's Mekong Basin Project and Kunming Initiative. The present Indian strategy appears to involve Myanmar in projects where the former exercises disproportionate power. Agreement has been reached on the construction and operation of a multi-modal transit and transport facility on the Kaladan River, connecting the port of Sittwe in Rakhine state to the Indian state of Mizoram. India is also interested in the construction of a pipeline for delivery of gas from the Shwe gas project off the coast of Arakan. Earlier negotiations with Bangladesh became stalled over the latter's demands in order for the pipeline to run through the country. India is now interested in running the pipeline over its own territory in the northwest together with the necessary infrastructure development to support it as well. And finally, whereas India is interested in developing the port of Yawei (Tavoy) in south Myanmar, it has not received interest from Myanmar authorities. India also tends to deal with China on a bilateral basis rather than in regional fora, notwithstanding a common interest in cultivating Myanmar. In fact, until recently when China announced its New Security Concept (NSC) that is much more favourable towards multilateral efforts at international problem solving, it tended to operate like India as well, often dealing with important relationships on a bilateral basis.

The India-Myanmar relationship is much less developed than the China-Myanmar one. Given the lesser flow of goods and people, there is also a lesser possibility of friction although more recently there have been greater Myanmar migrant and refugee movements into Mizoram in India. Problem areas in the past were primarily related to insurgency and the Indian preference for democracy and democracy activists in Myanmar over the military regime in power. However, the ideologically driven foreign policy has been changed in the 1990s in favour 
of a more accommodative approach. This policy is motivated, at least in part, by perceived vulnerabilities arising from a robust China-Myanmar bilateral relationship. The current trajectory of bilateral relations may however be subjected to change, depending on the calibration of the elected government in India although the Congress Party's stunning electoral victory in the 2009 election means that the current policy is likely to endure for some time.

\section{MYANMAR'S RELATIONS WITH THAILAND}

Historically, owing to geographical proximity and ethno-cultural and religious similarities, Thailand and Myanmar have had dense interactions. However, such interactions have not always been cordial or mutually beneficial. Historical memories of Thai-Burmese rivalry and in particular, Burmese assaults on Thai kingdoms in the seventeenth century are deeply ingrained in the mindset of the Thais (Ganesan 1999; Chachavalpongpun 2006). These memories often inform Thai perceptions of the Burmese, particularly when bilateral relations are strained. Conversely, for the Burmese, the current state of political and economic despair does not accurately represent their historical achievements in the immediate post-independence period when the country was commonly referred to as the "rice bowl of Asia". The post-1962 and in particular the post-1988 situations are viewed as difficult times brought on by internal political divisiveness and external exploitation. Such exploitation, especially in the economic realm, is sometimes attributed to Thailand and China. Notwithstanding such perceptions, typically referred to as an historical overhang in the literature in international relations, Burma's isolationist policy until 1988 and the relatively cordial ties that were maintained by the military elite of both countries insulated the relationship from tensions and conflict. These elite on the Thai side included but were not restricted to Generals Kriangsak Chomanand, Prem Tinsulanonda and Chaovalit Yongchaiyudh. Similar patterns of socialization, convergent interests in dominating the domestic political process and personal familiarity generally kept the bilateral relationship cordial during this period. Nonetheless, it should be noted that this third bilateral relationship is significantly more complicated than the previous two and subjected to much more domestic political considerations on the Thai side.

The issues involved in the mutually beneficial relationship between the two military governments were the second factor that insulated the bilateral relationship. Whereas Burma was richly endowed with natural wealth, its isolationist policy from 1962 meant that these resources could not be extracted and traded in the international market. Consequently, Thai military elite were uniquely placed to appropriate such opportunities. Especially important in this bilateral trading relationship were Burmese gems, teak and marine products. This economic relation- 
ship continues until today. Thailand was Myamar's top export destination in $2007 / 08$, absorbing some 44 percent of all exports with total bilateral trade valued at \$3.19 billion (Selected Monthly Ecopnomic Indicators 2008; Statistical Yearbook 2008; Xinhua January 30, 2009). Especially important in the trade is the Thai purchase of oil and gas from Myanmar. There are also significant Thai investments in Myanmar infrastructure and hydroelectric power projects along the Thanlwin River. Additionally, there is very dense cross border trade and growing border investment zone expansions between the two countries. Thailand is also home to a large number of both legal and illegal Myanmar workers who are often prepared to work for lower wages and under more difficult conditions than their Thai counterparts.

It was the election of the Chart Thai-led Chatichai Choonhavan government in August 1988 that disbanded the long-standing Thai policy of treating Vietnam as a security threat. Instead, Chatichai inaugurated a new "Indochina Initiative" that promised to transform the battefields of Vietnam into market places (Um 1991). Whereas the events of 1988 in Thailand were important in redefining Thai foreign policy output towards Vietnam, domestic political developments in Burma at the same time, also led to significant changes in bilateral relations between the two countries. As Vietnam receded into the background as a security threat, the violence associated with the collapse of the BSPP government and the resumption of heavy fighting between the Myanmar military junta and ethnic insurgents along the border with Thailand elevated the importance of Myanmar as a threat to Thai national security.

If domestic political developments in both Burma and Thailand insulated the bilateral relationship from deteriorating for some 30 years, it can be persuasively argued that these same developments led to a relationship that rapidly deteriorated in the $1990 \mathrm{~s}$. In the case of Burma, it was the political liberalization leading to the democratic elections of 1990 and the ensuing political violence and harassment of the opposition by the military, which refused to accept a reduced role in the domestic political process. In the case of Thailand, it was a discredited military that was forced to concede power to democratically elected governments that Sukhumphand Paribatra and Kraisak Choonhavan were more concerned with representation and accountability rather than political and economic gains. In fact, the Chatichai government and its group of advisors that downgraded Vietnam as a security threat and upgraded Burma as the new threat provided the foundation for Thai revisionist policy towards Myanmar in the 1990s.

The election of two governments led by the Democrat Party from 1993 to 1995 in the first instance, and 1997 to 2001 in the second instance set the stage for a hardening of Thailand's foreign policy towards the military junta in Myanmar. Coinciding with the changes in Thailand was a hardening of position by the Myanmar military junta towards the political opposition and the ethnic insurgencies. The former group had dissidents in Thailand that highlighted the 
abuses of the junta to a sympathetic government. Elements of the latter group and especially the Karen National Union (KNU) and the Shan State Army -South (SSA-S) not only straddled the Thai-Myanmar border but their fighting with Myanmar troops often spilled across the border into Thailand's Mae Hong Son and Tak provinces. Hence, there was just cause for the Democrat government to adopt a more hard-line policy toward Myanmar (Ganesan 2001a). Myanmar's major military offensives against the KNU bases in Kawmoora and Manerplaw between 1993 and 1995 resulted in a steady stream of Karen refugees into Thailand. Up to 200,000 Karen refugees whose living conditions were often subjected to the scrutiny of the United Nations High Commissioner for Refugees (UNHCR) and other international Non-Governmental Organizations (NGOs) entered Thailand. Criticisms leveled against Thailand by the international community regarding the living conditions and security arrangements for these camps often placed the country in the international limelight negatively.

Democrat-led coalition governments retained their mistrust of the Myanmar government. The clearest evidence of this mistrust was calls by Thailand, together with the Philippines, for "flexible engagement," as opposed to the policy of "constructive engagement" that characterized earlier Thai policy output towards Myanmar in the early 1990s. The early policy yielded some positive gestures from the Myanmar junta. So, for example, after Myanmar acceded to the ASEAN Treaty of Amity and Cooperation in 1994, Aung San Suu Kyi was released from house arrest in 1995. However, after Myanmar's membership in ASEAN in July 1997, there was little evidence of further political change. Hence there was an attempt to revise ASEAN's policy towards Myanmar. Indonesia, Malaysia and Singapore were opposed to it since the terms of reference were unclear and there was a lurking suspicion that the new phrase implied intervention in Myanmar's domestic politics (Haacke 1999). There were however two incidents in 1999 and 2000 that strained Thai-Myanmar relations that in turn affected the Democrat-led government's perceptions of Myanmar's domestic politics (Ganesan 2001a).

In the first incident in 1999, a dissident student group took over the Myanmar embassy in Bangkok. The heavily armed group comprising five students held 38 hostages in the embassy to attract attention to their cause -the restoration of democracy in Myanmar. Swift Thai intervention defused the crisis within a day and both the hostages and dissidents were released. The Myanmar government was infuriated with the manner in which Thai authorities dealt with the crisis, which appeared to condone the dissidents' behavior. In a clear gesture of disapproval, the Myanmar government subsequently sealed all border crossings, including the Friendship Bridge, and crossings in Mae Sai and Ranong. Additionally, large reinforcements were sent to Tachilek, across the border from Mae Sai, and three patrol boats were deployed off Ranong. In the second related incident, armed Karen insurgents seized a hospital in Ratchaburi province in January 2000. Thai 
Special Forces subsequently stormed the hospital and killed all ten insurgents -an action that reflected the growing unhappiness of Thailand in being used to resolve the political stalemate in Myanmar.

In the 2001 Thai general election, the Thai Rak Thai party led by Thaksin Shinawatra won an overwhelming victory. This major change in the recalibration of Thai domestic politics in turn led to a much more accommodative policy towards Myanmar from 2001 to 2007. With Chaovalit and subsequently those closely associated with him acquiring the Defence portolio and Surakiat Sathirathai assuming the Foreign Affairs portfolio, there was a marked change in Thai policy towards Myanmar. Greater emphasis was placed on maintaining cordial relations with Myanmar, including the adoption of a low-keyed "Asian-style" response to solving intractable problems (Nation February 28, 2001). In fact, the situation was in stark contrast to previous policy output under the Chuan government.

Thailand's policy of accommodating Myanmar under Thaksin was certainly at odds with even its ASEAN counterparts. The Bangkok Process that was initiated by the Thaksin government to engage Myanmar and allow it to interact with other countries has fallen into disrepute. In 2004, the Myanmar government openly refused to participate in the Dialoguc, much to the chagrin of Thailand. With the Thai Rak Thai's massive electoral victory in the February 2005 election, Thai policy towards Myanmar continued to be favourable. In the aftermath of the September 2006 military coup, caretaker government and court decisions to ban Thai Rak Thai and the People's Power Party, the Democrat Party-led Abhisit Vejajiva formed the present government in December 2008. Democrat-led governments have traditionally been hostile towards the military junta in Myanmar and therefore the accommodative policies of the Thaksin government are likely to be reversed. The clearest evidence of this policy position is the strongly worded statement issued by Thailand condemning the trial of Aung San Suu Kyi for violating the terms of her house arrest in May 2009 (ChannelNews Asia May 19, 2009; Bangkok Post May 20, 2009). As Chair of ASEAN, Thailand issued a similarly worded statement on behalf of the organization as well. Myanmar, on its part, "strongly rejected" the Thai and ASEAN pronouncements and accused Thailand of attempting to interfere in the country's domestic politics (ChannelNews Asia May 25, 2009; Agence France Presse July 3, 2009; Nation July 1, 2009).15

Unlike the case with China and India, there are important domestic pressures on the Thai side of the equation. These pressures are a reference to powerful lobby groups like drug enforcement agencies, the Border Patrol Police and the Thai Army. Some of these groups are able to mobilize public opinion that forces the government to behave in a certain way. Enforcement agencies and the military are also often in a situation to deal with problems as they occur. Hence, like the navy that protects Thai trawlers in the Andaman Sea or the Third Army that is tasked with protecting the border areas with Myanmar, such agencies are able to steer a course of action that is sometimes independent of the wishes 
of the political elite. The previous Third Army commander certainly frustrated Thaksin on a number of occasions in 2001 when the latter first assumed office. Additionally, the Thaksin government itself was capable of high levels of nationalist rhetoric, just like the Myanmar military junta. Therefore, unlike the situation with China and India, Thailand's policy output towards Myanmar is subjected to many inputs and may occasionally appear fragmented on account of such interests.

The first and perhaps most serious issue that affects Thai-Myanmar relations has traditionally been ethnic insurgency in Myanmar that is in turn correlated to illegal migration and refugees. It should be noted at this juncture that Thai national security planners have always paid careful attention to natural barriers like rivers that define their territoriality. These rivers, together with powerful groups along their borders with neighbouring countries, were often consciously utlised as part of a broader buffer policy (Chachavalpongpun 2005). Traditionally, such rivers have included the Moei and the Thanlwin that border Myanmar, the Golok that borders Malaysia and the Mekong that borders the Indochinese states. When these natural perimeters are breached, the Thais tend to feel insecure. From the late 1980s onwards, the Myanmar government has had far better success in negotiating ceasefire agreements with ethnic insurgent movements and 17 groups now exist in relative peace with the government. Typically, such agreements allow the groups to retain their arms and confine themselves to a clearly defined and contiguous territory. It has been reported that even the NKU has recently broken ranks and attempted a truce with the government (New Light of Myanmar June 14, 2009). ${ }^{6}$ Separately, the United Nations has announced that some 50,000 Myanmar refugees currently housed in Thailand will be settled in the West (Nation July 1, 2009).

The second major issuc that has negatively affected Myanmar's relations with Thailand is narcotics. Whereas Myanmar has traditionally been a major producer of opium poppy and its derivatives like heroin, more recently, there is mounting evidence that it has also become a major producer of meta-amphetamine tablets. Especially worrisome for Thailand is the huge recent flow and easy availability of these synthetic drugs in the north of he country where addiction rates are high. Thailand and the US have also alleged that certain ethnic insurgent groups like the United Wa State Army (UWSA) and the Kokang are involved in the manufacture and distribution of synthetic drugs. The Myanmar government that relies on both these groups to administer their territories as part of the negotiated settlements is often accused of complicity in the drug trade. Additionally, the Myanmar government has in the past relied on the UWSA to engage a smaller anti-junta ethnic insurgent group-the Shan State Army-South (SSA-S). In February 2001, fighting along the Thai-Myanmar border spilled over into Thailand, leading to a serious engagement between the Myanmar military and the Thai Third Army. In December 2002, there was also a tense standoff between Myanmar 
and Thai troops at the border. The spread of HIV/AIDS, which is partly related to narcotics consumption, is also a growing problem. Consequently, narcotics as an issue, certainly harbours the potential to strain Thai-Myanmar relations in the future.

The third major issue that affects Thai-Myanmar relations is illegal fishing (Ganesan 2001b). Thai trawler operators have traditionally fished extensively in Myanmar's territorial waters, which are known for bountiful reserves of fish, especially in the Guif of Martaban. Myanmar, which has been subjected to international isolation and sanctions, implemented a scheme to sell fishing permits to Thai trawlers to boost foreign exchange earnings in the 1990s. Subsequently, evidence began to emerge of Myanmar unhappiness with Thai trawler operators, who were accused of fishing in restricted areas and duplicating permits. As a result, since 2000, Myanmar has suspended the sale of fishing permits to Thailand.

Description of a number of incidents involving fishing disputes provides some clues about the seriousness of the issue for Thai-Myanmar relations. In 1992, for example, Myanmar patrol craft attacked and sank 10 Thai fishing trawlers, which led to the presumed death of 200 crewmen. In another incident in 1994, Myanmar officials patrolling in a seized Thai trawler in the Andaman Sea were reported to have killed is Thai trawler crew members (Fairclough 1997). Although Myanmar suspended the sale of trawler licenses to Thailand since 2000, conflicts over fishing still occur from time to time. Consequently, it is arguable that like ethnic insurgency and drug trafficking, illegal fishing as an issue flares up from time to time and it certainly has the potential to lead to a significant downward spiral in the relationship. Heightened nationalist sentiments and the involvement of armed troops and enforcement agencies in all these issues also make the possibility of the outbreak of conflict very real. In this regard, the Thai-Myanmar bilateral relationship is far more prone to frictions than those between Myanmar on the one hand and China and India on the other.

Finally, it should be noted that both Thailand and India have traditionally been anxious about Sino-Myanmar cooperation, especially in military matters. Through supporting the Myanmar junta and offering the country development aid, China is likely to gain access to the Andaman Sea and the Bay of Bengal. Such access is a cause of concern to Thailand that has a naval base in Phang $\mathrm{Nga}$, and India that maintains a large naval facility in Port Blair in the Andaman Islands. Consequently, Myanmar's bilateral relationship with China may in turn impact on Thai-Myanmar relations. Presumably, it will lead to greater caution and in the event of a perceived threat from China, Thailand is likely to lean towards an external security guarantor as it has done so often in the past-a policy called bending with the wind. 


\section{CONCLUSIONS}

Myanmar's bilateral relations with its near neighbours-China, India and Thailandare significant and help stabilize the country's immediate external environment. They also help cushion the country from international pressures since these neighbours do not attach conditions to the engagement process. Whereas Myanmar laid early claim to a neutral and independent foreign policy, it was unable to pursue this stated goal. Subsequently, following the military coup in 1962 and the establishment of the BSPP government, it practiced a neutral policy that was defined by isolationism. Since the collapse of the BSPP government in 1988, Myanmar had attempted to reach out to the world but was in turn frustrated by international sanctions led by the US and the EU. The sanctions were a response to Myanmar's annulment of the 1990 national election that was won by the political opposition and widespread detention of opposition politicians. Consequently, it has reverted to a much more realist foreign policy that views international relations and power in competitive terms. This outlook is also informed by the military government's need to maintain its political-security complex or internal regime legitimacy. This domestic linkage conflates state security with regime security. Finally, relations with its near neighbours help Myanmar maintain a certain competitive balance-of-power among its major bilateral relationships and significantly retain sovereignty and latitude in foreign policy output within the realist tradition as well. The general opinion of the international community and observers of Myanmarese politics at this stage is that internal changes will take time to occur and even then, such changes are likely to have domestic rather than regional or international origins.

\section{REFERENCES}

Agence France Presse. 2009. UN Chief Says Burma Mission 'Very Difficult.' July 3.

Alagappa, Muthiah. 1998. Asian Security Practice: Material and Ideational Influences. Stanford: Stanford University Press.

Arnott, David. 2001. China-Burma Relations. In Challenges to Democratisation in Burma. Stockholm, SE: International Institute for Democracy and Electoral Assistance.

Asian Tribune. 2002. Myanmar Gets Low Caliber Indian Artillery. December 17. Bangkok Post. (Thai daily newspaper) 1995. November 19. 2009. Asean Calls for Suu Kyi's Release. May 20.

Bray, John. 1995. Burma and the Politics of Constructive Engagement. London: The Royal Institute of International Affairs.

Callahan, Mary P. 2004. War and State Building in Burma. Singapore: Singapore 
University Press.

Cameron, Fraser and Jarek M. Domanski. 2005. Russian Foreign Policy with Special Reference to its Western Neighbours. Brussels: European Policy Centre.

Chachavalpongpun, Pavin. 2005. A Plastic Nation: The Curse of Thainess in That-Burmese Relations. Lanham, Maryland: University Press of America.

ChannelNewsAsia. (Singapore news network) 2009. Asean Expresses Grave Concern over Aung San Suu Kyi's trial. May 19.

May 25.

2009. Myanmar 'Strongly Rejects' ASEAN Statement on Suu Kyi.

China Daily. 2003. China Opposes Interference in Myanmar. August 21.

Chi, Shad-liang. 1997. Burma's Relations With the People's Republic of China: From Delicate Friendship to Genuine Cooperation. In Burma: The Challenge of Change in a Divided Society, eds. Peter Carey. London: Macmillan Press.

Collier, Ruth Berrins and David Collier. 1991. Shaping the Political Arena. New Jersey: Princeton Universicy Press.

Davis, Anthony. 1999. Burma Casts Wary Eye on China, Jane's Intelligence Review. June 1, 1999.

Egreteau, Renaud. 2003. India and Burma/Myanmar Relations: From Idealism to Realism. Presented at a conference in Nete Delbi.

Fairclough, Gordon. 1997. Floating Flashpoint: Fishing Fleets Aggravate Regional Tensions. Far Eastern Economic Review.

Ganesan, N. 1999. Bilateral Tensions in Post-Cold War ASEAN. Singapore: Institute of Southeast Asian Studies.

2001a. Illegal Fishing and Illegal Migration in Thailand's Bilateral

Relations with Malaysia and Myanmar. In Non-Traditional Security Issues in Southeast Asia, eds. Andrew Tan and Kenneth Boutin. Singapore: Select Publishing for Institute of Defence and Strategic Studies.

. 2001b. Thailand's Relations with Malaysia and Myanmar in Post-Cold

War Southeast Asia. Japanese Journal of Political Science 2(1): 127-146. . 2005. Myanmar's Foreign Relations: Reaching out to the World.

In Myammar: Beyond Politios to Societal Imperatites, eds. Kyaw Yin Hlaing, Robert H. Taylor, and Tin Maung Maung Than. Singapore: Institute of Southeast Asian Studies.

2006. Thai-Myanmar-ASEAN Relations: The Politics of Face and

Grace. Asian Affairs: An American Review 33(3): 131-150.

Ganesan, N. and Ramses Amer. 2010. Between Bilateralism and Multilateralism:

Southeast Asian International Relations in Perspective. Singapore: Institute of Southeast Asian Studies, forthcoming.

Haacke, Jürgen. 1999. The Concept of Flexible Engagement and the Practice of Enhanced Interaction: Intramural Challenges to the 'ASEAN Way.' Pacific Review 12(4): 581-611.

. 2006. Myanmar's Foreign Policy: Domestic influences and international 
implications. London: International Institute for Strategic Studies. Adelphi paper 381.

Kyaw, Yin Hlaing. 2004. Myanmar in 2003: Frustration and Despair?. Asian Survey 44(1):87-92.

Malik, J. Mohan. 1994. Sino-Indian Rivalry in Myanmar: Implications for Regional Security. Contemporary Southeast Asia 16(2): 140.

. 1997. Myanmar's Role in Regional Security: Pawn or Pivot? Contemporary Southeast Asia 19(1).

Maung, Mya. 1994. On the Road to Mandalay: A Case Study of the Sinocization of Upper Burma. Asian Strvey 34(5): 446-59.

1998. The Burma Road to Capitalism: Economic Growth versus Democracy.

Westport, Connecticut: Praeger.

Morgenthau, Hans. 1978. Politios Among Nations: The Struggle for Power and Peace. $5^{\text {th }}$ eds. New York: Alfred A. Knopf.

Muni, S, D. 2001. Chincis Strategic Engagement with the New ASEAN. Singapore: Institute for Defence and Strategic Studies.

Nation. (A Thai daily nespaper) 2001. February 28:2009. 50,000 Burmese Refugees From Thai Border To Be Resettled In West. Says UN. July 1.

Suu Kyi. July 6.

2009. Burmese Junta To Refuse UN Chief to Visit Aung San

2009. Burmese Junta Issues A Warning To China. September 4.

New Light of Myanmar. (A Myanmar daily newspaper) 2009. Ministry of Foreign Affairs releases press statement in response to declaration of EU Presidency. June 14 .

People's Daily. (A Chinese daily newspaper) 2003. China, Myanmar to Step up Cooperation: Vice-Premier. January 15

Reuters. 2009. Myanmar Police Seize Drugs. September 4.

Rosenau, James N. ed. 1969. Linkage Politics: Essays on the Convergence of National and International systems. New York: The Free Press. Seekins, Donald M. 1997. Burma-China Relations: Playing with Fire. Asian Survey 37(6): 525-539.

Selected Monthly Economic Indicators(S MEI). 2008. (Yangon, Myanmar) September.

Selth, Andrew. 2002. Burma's Armed Forces: Power Without Glory. Norwalk, Connecticut: Eastbridge.

Selth, Andrew. 2007. Chinese Whispers: The Great Coco Island Mystery, Irrawaddy (online ed.).

Statistical Yearbook (SYB) 2008 (Yangon, Myanmar).

Taylor, Robert H. 1987. The State in Burma. Honolulu: University of Hawaii Press.

Taylor, Robert H. 2009. The State in Myammar. Honolulu: University of Hawaii Press. Thin, Thin Aung and Myint Soe. 2001. India-Burma Relations In Challenges 
to Democratization in Burma. Sweden: International Institute for Democracy and Electoral Assistance.

Um, Katharya. 1991. Thailand and the Dynamics of Economic and Security Complex in Mainland Southeast Asia. Comtemporary Southeast Asia 13(3): 127-146. Waltz, Kenneth N. 1959. Man, the State and War: A Theoretical Analysis. New York: Columbia University Press.

Xiao, Ren. 2009. The Fusion of Principle and Interest in Chinese Foreign Policy: The Case of the Myanmar Issue. Paper presented at a conference in Kunming. Ximhua. (Chinese official news agency). 2008. Myanmar, India to Cement Economic, Trade ties. November 24.

. 2009. Myanmar-Thai Bilateral Trade Hit Over $\$ 2$ bln in Eight Months of 2008-09. January 30. 


\section{ENDNOTES}

The terms Burma and Myanmar are used to simply denote the country. No connotative value is attached to either term although the latter has acquired negative value among some scholars and analysts. As used in this instance, the name Burma refers to the country prior to 1988. In 1989), the ruling military junta, the State Law and Order Restoration Committee (SLORC) renamed the country Myanmar. The latter name is subjected to dispute owing to the high level of political violence that accompanied leadership transition from 1988. It is also sometimes associated with tacit approval or support of the renamed State Peace and Development (SPDC) government,

Notwithstanding the different names that have been given to the military junta in power, the fact remains that it is a military regime. Although $\mathrm{Ne} W$ in officially stepped down from power in 1988, it is widely believed that he continued to exercise power until the time of his death in December 2002. The persons most closely associated with the current government are Generals Than Shwe, Maung Aye, Thura Shwe Mann and Thein Sein. Until his detention and fall from grace in October 2004, General Khin Nyunt who was head of military intelligence and Prime Minister was also strongly identified with the government.

The most significant of such visits on the Myanmar side include those of Than Shwe, Khin Nyunt, Maung Aye, David Abel. Tin Oo and Thein Win. On the Chinese side, Li Peng and Jiang Zemin visited Myanmar in 2000 and 2001 respectively, reaffirming cordial bilateral ries. In January 2003. Chinese Vice-Premier Li Lanqing, during a visit to Yangon, expressed the desire to push the bilateral relationship to a new and higher level. In March 2009, L.i Changchun, a member of the CCP's Political Bureau Standing Committee visited Yangon to sign joint agreements on constructing petroleum and natural gas pipelines as well as a framework agreement to jointly develop hydropower. Typically. Myanmar leaders like Maung Aye and Thura Shwe Mann pay two visits to China each year, one to Beijing and the other to Yunnan province that accounts for about half the value of all bilateral trade. The most recent visit by Maung Aye to Beijing in June 2009 also led to the signing of a number of bilateral agreements. Finally. Than Shwe has preterred to obtain medical treatment from (hina instead of Singapore since the former is able to provide more privacy and secrecy - Such facilities were rumoured to include those in Hainggyi in the Irrawady River estuary near Bassein, Ramree Island south of Sittwe in Arakan state, Zadetkyi Kyun (St. Matthew's island) off the Tenasserrim coast and Coco Island in the Andaman Sea.

This position is attributed to a statement made by General Zhao Nanqi. Director of the Chinese Academy of Military Sciences in 1993 in which he is reputed to have said that China cannot accept the Indian Ocean being India's Ocean.

Most writers refer to a large defence procurement exercise in August 1990 valued at some US\$1.4 billion as the start of this weapons acquisition programme. Such acquisitions include fighter, ground attack and trainer aircraft. frigates and fast patrol boats, main battle tanks and armoured personnel carriers, anti-aircraft guns and missiles and assorted small arms. Between 2001 and July 2003 alone. I shipments of weapons were reported.

China is itself wary of the inflow of drugs from Myanmar and the international community has expressed reservations about the drug-related activities of certain ethnic groups, in particular the Shan, Wa and the Kokang. In late August 2009, the Myanmat military engaged the Kokang 1,000 strong Myanmar National Democratic Alliance Army (MNDAA) that in turn led to some 30,000 Kokang and ethnic Chinese crossing the border into Yunnan province. The action drew a rare rebuke from the Chinese government. The Myanmar government claimed that it was raiding a drug factory while detractors emphasized the action as a signal to other ceasefire groups and part of preparations for the 2010 national election. Eventually however, a large quantity of methamphetamine tablets and precursors were seized, validating the junta's claims.

* For example, in 1998, the Myanmar government announced a restricted list of items for import and export, leading to a fall in the total bilateral trade turnover from $\$ 749$ million in 1997 to $\$ 400$ million in 1998. Davis, 3. It has also been reported that the SPDC apparently turned down a Chinese proposal to build a container port at Bhamo and improve the port facilities at Kyaukpyu in Rakhine state.

ye common 1,643 kilometre-long common border is shared with the Indian provinces of Arunachal Pradesh, Nagaland, Manipur and Mizoram

10. It was also noted that Indian Defence Minister George Fernandes sheltered student activists from Myanmar and was a harsh critic of the military government

14 The border agreement resulted in the opening of a cross-border point between Moreh in Manipur, India and Tamu in Sagaing Division, Myanmar. India is also building the Monywa-Kalaywa Road, together with two major tiver bridges in Myanmar. The military operations targeted the United Liberaton Front of Assam, National Socialist Council of Nagaland, People's Liberation Army of Manipur, Manipur People's Liberation Front and the Kuki National Army 
12 In recent times, such visits on the Myanmar side have included those of Ket Swein, U Nyunt Swe, Tun Kyi, Tin Haing, Nyunt Tin, U Thaung, and General Maung Aye. Maung Aye's most recent visit was in April 2008. On the Indian side, officials include P. Chidambaram, Saleem Shervani, P. P. Prabhu, K. Ragunath, L. K. Advani, Ram Krishna Hegde and Army Chief V. P. Malik. Maung Aye's April 2008 visit was reciprocated by Indian foreign secretary Shivshankar Menon in November 2008 at which time 3 memoranda wete signed in Naypyidaw.

In September 1998, Indian police arrested 6i Myanmar activists who were subsequently charged and then released on bail. Similarly, in February 1999, another 50 activists were arrested and charged In 1998, the Indian Home Ministry intervened to cancel a seminar on Burma at the Constitution Club in New Delhi. Additionally, it is reported that the Home Ministry requested that Myanmar nationals not be recognized as refugees by the United Nations Migh Commissiunct for Refugees (UNHCR) Office in New Delhi. In July 1999, the Indian government also banned a Burma Democracy Conference to be held in Calcutta and refused to issue visas to Myanmar activists in exile. There has also been much more joint crackdown on insurgency movements by both countries. So for example, between 1995 and 1999. India's Assam Ritles have put great military pressure on the Chin National Front (CNF) in Mizoram to enter a ceasefire agreement with the Myanmar government, The Indian Armed Forces launched "Operation Leech" in the border areas in February 1998 and ceased a large quantity of weapons and ammunition. During the operation 6 leaders of the National United Party of Arakan were killed and another 73 were captured. Finally, in August 1999. Myanmar soldiers entered 300 metres inside Indian territory, in hot pursuit of Arakan Muslim insurgents and the intrusion was deemed "accidental."

"The weapon shipment includes 80 Indian-made $75 \mathrm{~mm}$. mountain guns and 30 truckloads of signaling devices and ammunition. More recently, high level military exchanges included the visit of the Indian Naval Chief M. Singh to Yangon and the visit of Myanmar Air Force Chief Myat Hein to New
Delhi in September 2003 .

In June 2009. UN special envoy Ibrahim Gambari visited Myanmar to pave the way for the visit of Secretary General Ban Ki-moon in early July, Ban, who has expressly said that he will rry to visit Aung San Su $K y$ and members of cle political oppesition and ceasetife spreements, acknowledged the difficulty of his mission. Eventually. he was not allowed to meet Suu Kyi.

The 17 groups that had officially negotiated peace setelements with the government by 200 - $f$ include the Kachin Independence Organization (KJO). New Demoxratic Army (Kachin), Palaung State Liberation Organization, Myanmar National Democracy Alliance (Kokang), Kachin Defense Army, Myanmar National Solidarity Party (Wa), National Democracy Alliance Atmy Military Local Administration Committee (Shan/Akhar). Shan State Army, Pa-O National Otgarization, Shan State Nationalities People's Organization, Mong Tai Army (MTA), Kayan National Guard, Kayinni National Progressive Party, Kayan New Land Party, Kayinni National People's Liberation Front and New Mon State Party. The KNU that concluded a first round of peace talks has yet to ratify the agreement following the detention of Khin Nyunt and the demise of Saw Bo Mya in 2004. The Myanmar government reported that a 300-strong force led by Major General Hein Maung from the KNU/KNLA "returned to the legal fold" in February $200^{-}$. Additionally, it was reported that anorher 71 members led by Saw Nay Soe Mya, son of Saw Bo Mya, along with 88 family members "had also followed suit" in March 2009. The recent fighting along the Thai-Myanmar border between the tatmadaw and the KNU/KNL.A in June 2009 led to more refugees crossing the border into Tak province 